\title{
THE HOLLY FERN IN ALBERTA
}

D. F. BRUNTON, Interpretive Co-ordinator, Kananaskis Provincial Park, Canmore, Alberta TOL OMO

In his manual of Alberta flora, Moss describes the Holly fern (Polystichum lonchitis (L.) Roth) as occuring in Alberta only at Waterton National Park. ${ }^{2}$ Boivin indicates the more general "Southwestern Alberta" for range! The specimens preserved in the University of Alberta and University of Calgary herbaria also support this picture of its distribution.

A number of new stations have been discovered in the last few years which markedly extend the known range of the species northward in the Rocky Mountains of Alberta. Map 1 depicts the range of $P$. lonchitis in Alberta as we now know it.

The map is derived from the following collections and/or observations:

(A) Kananaskis Provincial Park

1. 1976 - Sept. 1 - Burstall Lakes Valley. (W. Nordstrom).

2. 1977 - June 7 - above $2135 \mathrm{~m}$ elevation by stream on Mt. Indefatigable. D. Paton 101. (Herbarium of D. Paton).

3. 1977 - June 10 - S. E. - facing avalanche meadow among rocks on Mt. Sarrail above Rawson Lake. ca. 2380 elevation. N. Kondla 1622. (ALTA.).

4. 1977 - July 17 - ENE of summit of Mount Black Prince at $2010 \mathrm{~m}$ elevation. (D. F. Brunton and D. Paton)

5. 1977 - Aug. 10 - scattered on slopes west of Lawson Lake, Upper Kananaskis River Valley, from 2320 to $2475 \mathrm{~m}$ elevation (D. F. Brunton and D. Paton).

(B) Kananaskis Valley

6. 1977 - July 1 - very common on northeast side of $\mathrm{Mt}$. Inflexible at 2260 m elevation. D. F. Brunton 1395. (DAO)

7. 1974 - Oct. 13 - on steep avalanche slopes above Ribbon Falls, Ribbon Creek. D. Jaques 5086. (University of Calgary).

(C) Banff National Park

8. 1977 - July 13 - abundant on rocky slopes in Palliser Pass at $2290 \mathrm{~m}$. $2400 \mathrm{~m}$ elevation (M. Dyer et al).

9. 1977 - Sept. 15 - 1 large patch on trail to Mirror Lake just below Agnes Lake (Lake Louise Area) at $2075 \mathrm{~m}$. elevation. (J. Christensen).

(D) Kakwa Park Reserve

10. 1977 - several stations noted during botanical inventory (D. Jaques).

Polystichum lonchitis is found on steep limestone and/or limestone shale slopes which are open and only slightly vegetated. It prefers avalanche slopes and snow bed situations where there is a good supply of ground moisture throughout the growing season. The plants are usually found sheltered by shrubbery and/or overhanging rock ledges or boulders. Indeed, in some sites (e.g. Site 5, Kananaskis Park) the plants are almost completely hidden by willow, honeysuckle, fir or spruce shrubbery. The Green Spleenwort (Asplenium viride Huds.) is often associated with it (e.g. at sites 4, 8, and 6).

$P$. lonchitis appears to be a species of high elevations. The lowest station we know of north of Waterton is at $2010 \mathrm{~m}$. A.S.L. (site 4) and here it was growing on a cool, east-north-eastfacing slope. As well, we found it at this site growing (in better form) up 
